from diamonds giving strong secondary effects were relatively weak, being barely visible on a fluorescent screen; those from diamonds giving very weak or no secondary diffraction were much stronger, the (111), (220), etc., reflexions being visible on a fluorescent screen in broad daylight not only in the "characteristic" position but also throughout the entire range of Laue reflexion. This confirms the observation that strong secondary diffraction is associated with powerful extinction effects.

K. Lonsdale.

H. SMITH.

Davy Faraday Research Laboratory,

Royal Institution,

London, W.1. July 28.

${ }^{1}$ Lonsdale, K., and Smith, H., NATURE, 148, 112 (1941).

2 Raman, C. V., and Nilakantan, P., Proc. Ind. Acad. Sci., 11A, 396 (1940).

${ }^{3}$ Raman, C. V., Nilakantan, P., and Rama Pisharoty, P., Nature, 147, 805 (1941).

\title{
Determination of Sex in Scalpellum
}

Sexual conditions in the Cirripedia are very varied $^{1}$. They comprise such species as :

(1) Hermaphrodite forms with 'complemental' males, for example, Scalpellum scalpellum, Ibla cumingii;

(2) Hermaphrodites with sterile complemental larvæ, for example, Rhizocephala ;

(3) Hermaphrodites only, for example, most Pedunculata (Lepas, Pollicipes, etc.), Operculata (Balanus, Coronula, etc.), Ascothoracica ;

(4) Females with complemental males, for example, Scalpellum velutinum, S. ornatum, Ibla quadrivalvis, Acrothoracica.

The chromosomes of Lepas anatifera, which falls into group 3, were examined by Witschi ${ }^{2}$. He found the diploid number to be 26 and showed that no distinguishable sex chromosomes were present.

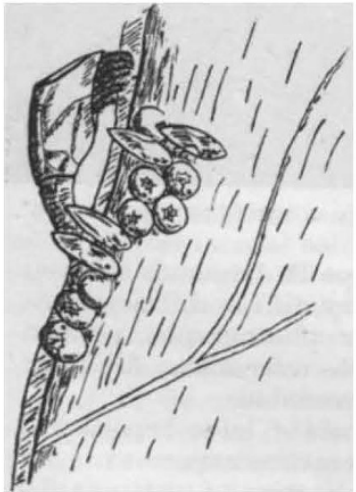

Group of CoMPlementals ATTACHED TO THE MANTLE OF A HERMAPHRODITE Scalpellum scalpellum, INCLUDING FOUR CYPRIS LARV A, NINE DWARF MALES AND ONE QUAST-HERMAPHRODITE. $(\times 12$.

were typical degenerate from the male-containing pocket of the hermaphrodite, had the structure of a small hermaphrodite (see accompanying illustration).

The absence of sex chromosomes, presence of oogonia in the complemental males and this odd hermaphrodite-like complemental point to an environmental control of sex determination such as that existing in Bonellia ${ }^{4}$. I would suggest, therefore, that in Scalpellum scalpellum and Cirripedes of its type all larvæ are potential hermaprodites (instead of female as in Bonellia), but those which become parasitic on adult hermaphrodites develop as functional males. only and go no farther. Since the breeding system involving complementals is widespread in the Cirripedes, it may further be suggested that this type of sex determination is primitive for the group.

John Innes Horticultural Institution,

$$
\text { Merton, S.W.19. Aug. } 2 .
$$

\footnotetext{
'Darwin, C., "A Monograph of the Sub-class Cirripedia" (London, 1851 and 1854).

${ }^{2}$ Witschi, E., Biol. Bull. Woods Hole, 68 (1935).

${ }^{3}$ Gruvel, A., "Monographie des Cirrhipedes"' (Paris, 1905).

4 Baltzer, F., Mitt. Zool. Stat. Neapel, 22 (1914).
}

\section{Albert Hall Acoustics}

THE changes made to house the recent season of Promenade Concerts have affected the appearance more than the acoustics of the Albert Hall. The subject has been discussed periodically ever since the Hall was built, but the oval ground plan and the great height are insuperable difficulties with reflecting surfaces. Most of the changes proposed, including that of Bagenal and Wood illustrated on p. 65 of their "Planning for Good Acoustics", showing the source of sound placed far above ground-level, attempt to preserve the full seating capacity of the Hall. Recently conditions have changed considerably. For some time pugilists and politicians have been the chief users of the full capacity of the Hall. But now there are a number of recognized sporting-centres in London and politicians can address even larger audiences through the radio. Musicians have, however, lost the Queen's Hall and other concert halls.

It would appear, therefore, that, when construction takes the place of destruction, the principle of 'divide and rule' could with advantage be applied to the recalcitrant acoustics. One half of the building could be used for a concert hall seating about five thousand, the number said to be needed for unsubsidized orchestral concerts in London. The remainder could be cut up to house smaller concert and recital halls, studios, a musical library, cafés, cloak rooms, ventilating plant and other needs of a musical centre. The volume of the Hall is adequate for all these needs. Although the fan shape is one of the simplest to plan acoustically, suggesting a division into wedge-shaped sections, like cutting a cake, the actual details of the division would be more a matter of structural engineering. Drastic changes of ground plan are essential. The most difficult acoustical problem would be the sound insulation of the different halls so that, if needed, they could be used at the same time. The division of the Hall would provide excellent support for roof gardens, like some of those in New York, where music and drama could be enjoyed out of doors in the summer time. The gardens would be well out of the range of appreciable traffic noise, and carefully planned stone wall screens could act as sound reflectors as in the typical Greek theatre.

Success would probably be best ensured by employing engineers and physicists under the direction of a fanatically functional architect.

Department of Physics, W. H. George

Chelsea Polytechnic, S.W.3. 